\title{
Pengembangan Modul Analisis Penggunaan Bahasa Indonesia Mahasiswa Semester VI Program Studi Pendidikan Bahasa dan Sastra Indonesia di STKIP PGRI Lubuklinggau
}

\author{
Dian Ramadan Lazuardi
}

(corresponding author)

STKIP PGRI Lubuklinggau

Email: dianramadan78@gmail.com

\section{Sri Murti}

STKIP PGRI Lubuklinggau

Email: srimurti05@gmail.com

\section{Adi Rohman}

STKIP PGRI Lubuklinggau

Email: adirohman883@gmail.com

\author{
Sintiyah Permata Sari \\ STKIP PGRI Lubuklinggau \\ Email: sintiyah@yaoho.com
}

APA Citation: Lazuardi, D.R., Murti, S., Rohman, A., \& Sari, S.P. (2021). Pengembangan Modul Analisis Penggunaan Bahasa Indonesia Mahasiswa Semester VI Program Studi Pendidikan Bahasa dan Sastra Indonesia di STKIP PGRI Lubuklinggau. Silampari Bisa: Jurnal Penelitian Pendidikan Bahasa Indonesia, Daerah, dan Asing, 4(2), 330-342. https://doi.org/10.31540/silamparibisa.v4i2.1286

\begin{abstract}
Abstrak
Ketersediaan buku-buku yang berkaitan dengan Mata Kuliah Analisis Penggunaan Bahasa Indonesia di tingkat perguruan tinggi masih sangat sedikit. Hal ini terbukti peredaran buku terkait Mata Kuliah Analisis Penggunaan Bahasa Indonesia tidak tersedia di pasaran maupun buku-buku yang berbasis e-book di internet. Untuk itu, diperlukan pemahaman materi yang lebih untuk dapat menguasai capaian pembelajaran. Untuk mencapai hal tersebut tidak bisa hanya mengandalkan dari penjelasan dosen saja. Diperlukan dukungan dari sumber belajar yang dapat digunakan untuk belajar secara mandiri. Terlebih setiap siswa memiliki kecepatan dan daya tangkap berbeda-beda, namun, bahan ajar yang dapat digunakan mandiri oleh mahasiswa belum tersedia. Agar tujuan akhir dari perkuliahan ini tercapai, maka diperlukan bahan ajar yang sesuai dengan kebutuhan mahasiswa Program Studi Pendidikan Bahasa dan Sastra Indonesia STKIP PGRI Lubuklinggau. Bahan ajar yang diperlukan diharapkan berdasarkan gejala-gejala kebahasaan yang ditemukan dalam penelitian. Hasil uji validitas
\end{abstract}


yang dilakukan pada tiga orang ahli menunjukkan bahwa modul Analisis Penggunaan Bahasa Indonesia valid dengan ciri khas modul adalah modul yang dikembangkan dengan penyajian interaksi (stimulus dan respon). Hasil uji kepraktisan berdasarkan uji protipe yang meliputi evaluasi one to one, evaluasi kelompok kecil, dan evaluasi kelompok besar dapat disimpulkan bahwa modul Analisis Penggunaan Bahasa Indonesia efektif digunakan dalam proses perkuliahan. Pada tahap uji formatif dapat disimpulkan bahwa mahasiswa dapat memahami materi dengan baik setelah menggunakan modul Analisis Penggunaan Bahasa Indonesia.

Kata kunci: pengembangan, modul, analisis penggunaan bahasa Indonesia

\title{
Development of Indonesian Use Analysis Module for Semester VI Students Indonesian Literature and Language Education Study Program at STKIP PGRI Lubuklinggau
}

\begin{abstract}
The availability of books related to the Indonesian Language Use Analysis course at the university level is still very few. This is proven by the circulation of books related to the Indonesian Language Usage Analysis course which is not available in the market or books based on e-books on the internet. For this reason, more understanding of the material is needed to be able to master learning outcomes. To achieve this, you can't just rely on the lecturer's explanation. Support is needed from learning resources that can be used for independent study. Moreover, each student has different speed and grasping power, however, teaching materials that can be used independently by students are not yet available. In order to achieve the ultimate goal of this course, teaching materials are needed that are in accordance with the needs of students of the Indonesian Language and Literature Education Study Program STKIP PGRI Lubuklinggau. The required teaching materials are expected based on the linguistic symptoms found in the research. The results of the validity test conducted on three experts showed that the Indonesian Language Usage Analysis module was valid with the hallmark of the module being a module that was developed with the presentation of interactions (stimulus and response). The results of the practicality test based on the prototype test which includes one to one evaluation, small group evaluation and large group evaluation, it can be concluded that the Indonesian Language Usage Analysis module is effectively used in the lecture process. At the formative test stage, it can be concluded that students can understand the material well after using the Indonesian Language Usage Analysis module.
\end{abstract}

Keywords: development, module, analysis use Indonesian

\section{A. Pendahuluan}

Proses perkuliahan merupakan suatu kegiatan yang melibatkan seseorang dalam upaya memperoleh pengetahuan, keterampilan dan nilai-nilai positif dengan memanfaatkan berbagai sumber untuk belajar. Dalam proses perkuliahan di perguruan tinggi melibatkan dua pihak yaitu mahasiswa sebagai pembelajar dan dosen sebagai fasilitator. Pratama (2020) menjelaskan bahwa cara belajar dan mengajar mencerminkan kecenderungan modalitas seseorang, namun penelitian menunjukkan bahwa semakin banyak modalitas yang dilibatkan secara 
bersamaan, proses belajar akan semakin hidup, berati, dan melekat. Dalam proses belajar membutuhkan interaksi, hal ini menunjukkan bahwa proses perkuliahan merupakan proses komunikasi yang di dalamnya terdapat penyampaian pesan antara dosen dan mahasiswa.

Setiap praktik dalam proses perkuliahan diarahkan pada pencapaian tujuantujuan tertentu, yang berkaitan dengan penguasaan pengetahuan, pengembangan pribadi, kemampuan sosial ataupun kemampuan bekerja. Seorang dosen sebagai pengajar harus mampu menampilkan gaya mengajar, tidak hanya berpikir bagaimana sebuah materi disampaikan, akan tetapi bagaimana proses transfer pengetahuan berpengaruh terhadap kehidupan peserta didik (Putra dkk., 2017). Untuk mencapai tujuan tersebut diperlukan kemampuan dalam mengembangkan inovasi pembelajaran salah satunya adalah mengembangkan modul dalam proses perkuliahan. Sesuai pendapat Asyhar (2013:155) dan Widodo \& Jasmadi (2008) menjelaskan bahwa sebaiknya modul yang dikembangkan tersebut harus mampu meningkatkan motivasi peserta didik dan efektif dalam mencapai kompetensi yang diharapkan sesuai dengan tingkat kompleksitasnya.

Modul adalah salah satu bentuk bahan ajar yang dibuat dengan dicetak serta dirancang untuk belajar secara mandiri oleh peserta didik (Wahayuningrum, 2019; Rohmah, 2020). Biasanya modul dapat dikembangkan sendiri oleh pendidik dengan tujuan dapat membuat materi sesuai dengan kondisi peserta didiknya. Dalam konteks mengajar di Perguruan Tinggi, khususnya pada mata kuliah Analisis Penggunaan Bahasa Indonesia, seorang dosen memberikan perkuliahan dengan harapan dapat memberikan informasi dari bahan ajar yang digunakan mahasiswa. Informasi yang didapatkan tersebut diharapkan dapat membantu mahasiswa dalam mengembangkan informasi tersebut di luar perkuliahan. Kenyataannya, bahwa bahan ajar yang tersedia saat ini belum sesuai kebutuhan dan ketersediaan buku-buku berkaitan dengan mata kuliah sangat sedikit di pasaran bahkan di internet pun sulit untuk didapatkan. Kalaupun ada, bahan ajar yang ada hanya mampu memberikan informasi secara teori tanpa ada hasil dari pemikiran mahasiswa.

Mata Kuliah Analisis Penggunaan Bahasa Indonesia merupakan mata kuliah yang bertujuan untuk memberikan pemahaman serta kemampuan dalam menemukan kesalahan dalam berbahasa dan bentuk-bentuk penggunaan bahasa Indonesia yang digunakan dalam kehidupan sehari-hari baik secara lisan maupun tulisan. Dengan demikian, sebagai orang bahasa terutama bahasa Indonesia, diharapkan mahasiswa mampu mengritisi gejala-gejala dalam berbahasa. Salah satu faktor kesulitan dalam proses perkuliahan adalah sulitnya memahami materi dikarenakan minimnya sumber belajar. Ketersediaan buku-buku yang berkaitan dengan Mata Kuliah Analisis Penggunaan Bahasa Indonesia masih sangat sedikit sekali bahkan di pasaran pun sangat sulit didapatkan bahkan untuk mengakses di internet pun juga tidak banyak ditemukan. Untuk itu, diperlukan pemahaman materi yang lebih untuk dapat menguasai capaian pembelajaran.

Untuk mencapai hal tersebut tidak bisa hanya mengandalkan dari penjelasan dosen saja. Diperlukan dukungan dari sumber belajar yang dapat digunakan untuk

Silampari Bisa: Jurnal Penelitian Pendidikan Bahasa Indonesia, Daerah, dan Asing Vol. 4, No. 2, 2021 
belajar secara mandiri. Terlebih setiap mahasiswa memiliki kecepatan dan daya tangkap berbeda-beda, namun, bahan ajar yang dapat digunakan mandiri oleh mahasiswa belum tersedia. Berdasarkan nilai akhir perkuliahan Analisis Penggunaan Bahasa Indonesia tahun akademik 2019/2020, maka diperoleh nilai rata-rata sebesar 81,6 yang jika dikonversikan ke angka berada di taraf (A-) maka masih dianggap sebagai nilai yang belum maksimal, hanya saja penilaian yang digunakan oleh kampus STKIP PGRI Lubuklinggau menggunakan konversi angka A-E. Hal ini disebabkan proses perkuliahan yang tidak didukung oleh bahan ajar yang baik sehingga tujuan pembelajaran tidak tercapai secara maksimal.

Agar tujuan akhir dari perkuliahan ini tercapai, maka diperlukan bahan ajar yang sesuai dengan kebutuhan mahasiswa Program Studi Pendidikan Bahasa dan Sastra Indonesia STKIP PGRI Lubuklinggau. Bahan ajar yang diperlukan diharapkan berdasarkan gejala-gejala kebahasaan yang ditemukan dalam penelitian. Menurut Satinem, dkk. (2020) menjelaskan bahwa telah menjadi kewajiban bagi dosen untuk mendesain pengajaran bahan itu sendiri. Bahan ajar itu hasil dari pembangunan akan lebih banyak bermanfaat bagi siswa karena materinya disampaikan sesuai dengan keinginan dan kebutuhan siswa (Ramadania, 2013; Sadjati, 2012). Jelas yang dimaksudkan adalah seorang dosen sebagai pendidik wajib memiliki kemampuan dalam mendesain bahan ajar agar mampu mencapai tujuan pembelajaran yang diharapkan.

Penelitian relevan yang digunakan dalam penelitian ini adalah penelitian yang dilakukan oleh Satinem (2020) dengan judul "Developing Teaching Material of Poetry Appreciation Based on Students' Competency Analysis". Adapun hasil penelitian ini menjelaskan bahwa rata-rata kemampuan siswa mengapresiasi puisi setelah menggunakan bahan ajar sebagai hasil pengembangan adalah sama dengan 70 atau lebih 70. Dengan demikian, model bahan ajar yang dikembangkan sudah layak dan efektif bagi dosen. Persamaan yang dilakukan oleh peneliti adalah sama-sama melakukan penelitian pengembangan bahan ajar di tingkat perguruan tinggi. Perbedaannya adalah bahan ajar yang dikembangkan oleh penelitian relevan adalah disesuaikan dengan kemampuan analisis mahasiswa sedangkan penelitian yang akan dilakukan oleh peneliti adalah bahan ajar yang dikembangkan penulis berbasis tekstual. Penelitian untuk Mata Kuliah Analisis Penggunaan Bahasa Indonesia belum pernah diteliti sebelumnya, bahkan belum ditemukan penelitian yang terkait mata kuliah ini.

Selain itu, penelitian relevan yang digunakan adalah penelitian Murti \& Lazuardi (2019) dengan judul penelitian Pengembangan Bahan Ajar Mata Kuliah Konsep Dasar Bahasa dan Sastra Indonesia. Persamaan penelitian yang digunakan adalah sama-sama mengembangkan bahan ajar di tingkat perguruan tinggi dengan menekankan pada pembelajaran bahasa Indonesia sedangkan perbedaannya adalah terletak pada pendekatan yang digunakan dalam mengembangkan bahan ajarnya.

Penelitian relevan selanjutnya dilakukan oleh Arsanti (2018) hasil penelitian ini menjelaskan bahwa bahan ajar bermuatan nilai regius pada Mata Kuliah Penulisan Kreatif layak digunakan dalam perkuliahan. Persamaan penelitian yang dilakukan oleh peneliti adalah sama-sama megembangkan bahan ajar di perguruan

Silampari Bisa: Jurnal Penelitian Pendidikan Bahasa Indonesia, Daerah, dan Asing Vol. 4, No. 2, 2021 
tinggi, dan perbedaannya adalah terletak pada rumusan masalah yang digunakan dimana penelitian relevan hanya melihat sejauh mana kelayakan bahan ajar sedangkan penelitian yang akan dilakukan adalah melihat keefektifan bahan ajar.

Berdasarkan latar belakang di atas, peneliti ingin melakukan penelitian dengan judul "Pengembangan Modul Analisis Penggunaan Bahasa Indonesia Mahasiswa Semester VI (Enam) Program Studi Pendidikan Bahasa dan Sastra Indonesia di STKIP PGRI Lubuklinggau". Modul yang akan dikembangkan oleh penulis diharapkan mampu memberikan interaksi (stimulus-respons) antara dosen dan mahasiswa.

\section{B. Metode Penelitian}

Penelitian ini menggunakan pendekatan R\&D (Research and Development) yaitu metode penelitian yang digunakan untuk menghasilkan produk tertentu dan menguji kefektifan produk tersebut (Sugiyono, 2013). Pengembangan model bahan ajar yang peneliti gunakan yaitu Model Dick \& Carey. Model yang dirancang dan dikembangkan oleh Dick \& Carey sering digunakan dalam penelitian dan pengembangan secara luas, sehingga keberhasilan model Dick \& Carey juga telah teruji. Menurut Dick \& Carey (dalam Setyosari, 2015) terdapat sepuluh langkah yang harus dilaksanakan dalam mengembangkan bahan ajar, namun peneliti tidak menggunakan seluruh langkah model Dick \& Carey.

Adapun langkah-langkah dalam pengembangan modul yang dilakukan peneliti adalah sebagai berikut: a) analisis kebutuhan dan tujuan, pada tahapan ini proses yang dilakukan berupa identifikasi kondisi mahasiswa semester 6 yang mengambil mata kuliah Analisis Penggunaan Bahasa Indonesia; b) identifikasi pembelajaran, tahapan ini menyesuaikan tujuan pembelajaran dengan RPKPS yang digunakan; c) analisis pembelajaran (siswa) dan konteks, yang dilakukan oleh peneliti adalah melihat kemampuan, sikap, dan karateristik awal pembelajaran; d) merumuskan tujuan performansi, tahapan ini adalah dosen membuat tujuan instruksional, capaian pembelajaran dan manfaat bagi mahasiswa; e) mengembangkan instrumen, instrumen yang dikembangkan berdasarkan tujuan pembelajaran yang dibuat berbentuk soal uraian/ esai dengan tingkat pemahaman mahasiswa; f) mengembangkan strategi pembelajaran, strategi yang dilakukan oleh seorang dosen adalah mengembangkan materi sesuai dengan RPKPS; g) mengembangkan dan memilih bahan pembelajaran; $h$ ) merancang dan melakukan evaluasi formatif; dan i) melakukan revisi, tahapan ini melalui tahapan evaluasi ahli, evaluasi perorangan, evaluasi kelompok kecil, dan uji lapangan.

Instrumen penelitian yang digunakan dalam penelitian ini: a). wawancara, wawancara dilakukan dengan mengajukan pertanyaan kepada mahasiswa semester 6 yang mengambil Mata Kuliah Analisis Penggunaan Bahasa Indonesia; b) kuisioner, kuesioner yang digunakan adalah kuesioner tertutup yang diberikan kepada validator dan mahasiswa; c) tes, tes yang diberikan berupa tes formatif. Teknik analisis data yang terdapat dalam penelitian ini berupa analisis data wawancara yang dilakukan secara langsung dengan melihat respons mahasiswa

Silampari Bisa: Jurnal Penelitian Pendidikan Bahasa Indonesia, Daerah, dan Asing Vol. 4, No. 2, 2021 
Dian Ramadan Lazuardi, Sri Murti, Adi Rohman, Sintiyah Permata Sari

Pengembangan Modul Analisis Penggunaan Bahasa Indonesia Mahasiswa Semester VI Program Studi Pendidikan Bahasa dan Sastra Indonesia di STKIP PGRI Lubuklinggau

mengenai bahan ajar Mata Kuliah Analisis Penggunaan Bahasa Indonesia yang selama ini digunakan, baik dari aspek materi maupun desain. Selain itu, analisis data angket menganalisis data kuantitatif menjadi kualitatif guna mengukur sikap siswa terhadap Modul Analisis Penggunaan Bahasa Indonesia dengan menggunakan angket tertutup. Analisis data tes yang digunakan adalah memberikan skor sesuai kriteria menganalisis penggunaan bahasa Indonesia yang meliputi skor 1-4.

\section{Hasil Penelitian dan Pembahasan \\ 1. Hasil Penelitian}

Hasil penelitian pengembangan bahan ajar Mata Kuliah Analisis Penggunaan Bahasa Indonesia melalui tiga tahap, yaitu tahap menganalisis, tahap mengembangkan, serta tahap evaluasi dan revisi. Tujuan melakukan tahap-tahap tersebut untuk mendapatkan bahan ajar yang valid, praktis, dan efektif. Berikut ini tahapan-tahapan yang harus dilakukan peneliti.

\section{a. Analisis Kebutuhan dan Tujuan}

Pada tahapan ini proses yang dilakukan adalah mengidentifikasi bahan ajar dan mengidentifikasi kesenjangan keadaan sekarang dan yang diharapkan oleh mahasiswa tentang bahan ajar yang memiliki kelengkapan materi dan menarik. Adapun langkah-langkah dalam menganalisis kebutuhan pembelajaran sebagai berikut.

1). Menganalisis Tujuan Pembuatan Bahan Ajar

Pada langkah ini, analisis yang dilakukan adalah mengidentifikasi kondisi mahasiswa Program Studi Pendidikan Bahasa dan Sastra Indonesia semester 6 yang mengambil Mata Kuliah Analisis Penggunaan Bahasa Indonesia. Pada proses perkuliahan sebelum proses pengembanagan bahan ajar dilakukan, dosen menggunakan berbagai buku cetak dan permasalahannya adalah tidak semua mahasiswa memiliki buku dan mampu membeli buku cetak tersebut. Hal inilah yang menyebabkan perkuliahan Analisis Penggunaan Bahasa Indonesia hanya bergerak satu arah. Bahkan kesulitan dalam mengevaluasipun dirasakan oleh dosen pengajar. Dengan pengembangan bahan ajar Mata Kuliah Analisis Penggunaan Bahasa Indonesia dapat membantu proses perkuliahan dan meningkatkan minat belajar mahasiswa.

2). Analisis Kesenjangan Keadaan Sekarang dan Keadaan yang Diharapkan

Kesenjangan keadaan sekarang dan keadaan yang diharapkan, dimana bahan ajar yang digunakan belum memfasilitasi mahasiswa seutuhnya, diharapkan setelah adanya bahan ajar Mata Kuliah Analisis Penggunaan Bahasa Indonesia dalam proses perkuliahan.

\section{b. Identifikasi Pembelajaran}

Setelah melakukan analisis kebutuhan pembelajaran, langkah selanjutnya yaitu melakukan analisis pembelajaran. Analisis pembelajaran dilakukan untuk menentukan keterampilan, proses, prosedur, dan tugas-tugas belajar untuk mencapai tujuan pembelajaran yang disesuaikan dengan Rencana Program dan Kegiatan Pembelajaran Semester (RPKPS). Materi yang diambil adalah materi

Silampari Bisa: Jurnal Penelitian Pendidikan Bahasa Indonesia, Daerah, dan Asing Vol. 4, No. 2, 2021 
Dian Ramadan Lazuardi, Sri Murti, Adi Rohman, Sintiyah Permata Sari

Pengembangan Modul Analisis Penggunaan Bahasa Indonesia Mahasiswa Semester VI Program Studi Pendidikan Bahasa dan Sastra Indonesia di STKIP PGRI Lubuklinggau

yang diajar sebanyak dua pertemuan yaitu tentang Kategori Kesalahan Berbahasa. Materi tersebut terdiri dari empat sub pokok bahasan sehingga setiap pertemuan membahas dua sub pokok bahasan.

\section{c. Analisis Pembelajar (Mahasiswa) dan Konteks}

Analisis pembelajar (mahasiswa) dan konteks yang dilakukan oleh peneliti yaitu menganalisis kemampuan, sikap, dan karakteristik awal pembelajaran. Berdasarkan hasil analisis kebutuhan maka dapat disimpulkan bahwa mahasiswa menginginkan bahan ajar yang mencakup materi yang lengkap, sehingga untuk pernyataan mengenai setuju pengembangan bahan ajar, mereka menjawab setuju dikembangkan bahan ajar seperti modul Analisis Penggunaan Bahasa Indonesia.

\section{d. Merumuskan Tujuan Performansi}

Merumuskan tujuan performansi yang dilakukan yaitu membuat tujuan instruksional, capaian pembelajaran dan manfaat bagi mahasiswa. Keseluruhan tujuan instruksional ini tergambar dalam RPKPS.

\section{e. Mengembangkan Instrumen}

Instrumen yang dibuat berbentuk soal uraian/ esai dengan tingkat jawaban mahasiswa meliputi pemahaman analisis mahasiswa. Soal dikembangkan berdasarkan tujuan pembelajaran yang didasarkan pada materi dari setiap materi.

\section{f. Mengembangkan Strategi Pembelajaran}

Berdasarkan informasi yang telah dikumpulkan sebelumnya, peneliti dapat menentukan strategi yang digunakan agar bahan ajar telah dirancang dapat mencapai tujuan yang telah ditentukan. Langkah awal yang dilakukan yaitu mengembangkan RPKPS untuk mengembangkan materi dalam bahan ajar ini.

\section{g. Mengembangkan dan Memilih Bahan Ajar}

Pada tahap ini penulis mengembangkan bahan ajar yang sesuai dengan kebutuhan pemakai yaitu dosen dan mahasiwa. Bahan ajar yang dikembangkan diharapkan dapat membantu mahasiswa dalam proses pembelajaran serta diharapkan bahan ajar yang dibuat menarik dan mudah untuk dipahami.

\section{h. Evaluasi Formatif dan Revisi}

Tahap terakhir dalam pengembangan bahan ajar menulis naskah drama yaitu tahap evaluasi dan revisi. Pada tahap ini evaluasi dan revisi dilakukan dalam beberapa rangkaian, yaitu a) evaluasi ahli; b) evaluasi perorangan; c) evaluasi kelompok kecil; dan d) uji lapangan.

1) Evaluasi Ahli

Pada evaluasi ahli dilakukan terhadap ahli bahasa, ahli kelayakan media, dan ahli isi. Instrument yang digunakan adalah angket terbuka, berdasarkan indikator dan saran yang dibutuhkan dalam mengembangkan bahan ajar Mata Kuliah Analisis Penggunaan Bahasa Indonesia.

Silampari Bisa: Jurnal Penelitian Pendidikan Bahasa Indonesia, Daerah, dan Asing Vol. 4, No. 2, 2021 


\section{a) Ahli Bahasa}

Validator ahli selanjutnya yaitu ahli bahasa yang juga ahli di bidangnya diambil dari salah satu dosen STKIP PGRI Lubuklinggau yaitu Dr. M. Syahrun Effendi, M.Pd. Angket yang diberikan sama dengan ahli desain yaitu angket terbuka dengan tujuh pertanyaan. Kritik dan juga saran disediakan oleh peneliti supaya peneliti mendapatkan masukan, dalam perbaikan bahan ajar Mata Kuliah Analisis Penggunaan Bahasa Indonesia. Komentar secara umum yang diberikan oleh validator bahasa adalah penggunaan bahasa yang digunakan secara jelas dan komunikatif. Berdasarkan hasil perhitungan validasi maka dapat dikonvensikan hasil kelayakan ahli kebahasaan berada pada rentang persentase $80 \%$ dengan kategori Baik.

b) Ahli Kelayakan Desain

Adapun validator kelayakan desain merupakan salah satu dosen dari STKIPPGRI Lubuklinggau yang berkompeten dalam bidang desain yaitu Bapak Dr. Dodik Mulyono, M.Pd. Pertanyaan validasi desain terdiri dari sepuluh butir pertanyaan untuk mengevaluasi kelayakan penyajian Modul Konsep Dasar Bahasa dan Sastra Indonesia. Adapun saran dan komentar yang diberikn oleh ahli desain antara lain: (a) Cover mampu memvisualisasikan isi dari modul; (b) tambahkan peta konsep: (c) sistem tabel dan gambar tambahkan jika perlu memvisualisasikan materi pembelajaran: (d) secara keseluruhan sudah baik dan dapat diajukan: Adapun berdasarakan tabel kelayakan ahli desain dapat disimpulkan komponen kelayakan desain termasuk dalam kategori baik, dengan persentase $82 \%$.

c) Ahli Kelayakan Isi/Materi

Validasi materi adalah seorang dosen yang telah ahli di bidangnya dan telah mengajar dalam kurun waktu yang lama, yaitu lbu Dr. Satinem, M.Pd. yang merupakan dosen Prodi Pendidikan Bahasa dan Sastra Indonesia STKIP-PGRI Lubuklinggau. Kesimpulan komponen kelayakan kebahasaan termasuk dalam kategori baik, dengan persentase $80 \%$. Adapun hasil kelayakan keseluruhan dapat dilihat pada tabel di bawah.

Tabel 1. Hasil Kelayakan Keseluruhan Ahli Validator

\begin{tabular}{llccc}
\hline No. & Validator & $\begin{array}{c}\text { Skor yang } \\
\text { diperoleh }\end{array}$ & Persentase & Kategori \\
\hline 1 & Penyajian dan Kegerafikan & 41 & $82 \%$ & Baik \\
\hline 2 & Isi/Materi & 29 & $82,8 \%$ & Baik \\
\hline 3 & Kebahasaan & 28 & $80 \%$ & Baik \\
\hline & Total & 98 & $81,6 \%$ & Baik \\
\hline
\end{tabular}

Hasil penilaian modul Analisis Penggunaan Bahasa Indonesia secara rinci dapat di lihat pada tabel berikut.

Silampari Bisa: Jurnal Penelitian Pendidikan Bahasa Indonesia, Daerah, dan Asing Vol. 4, No. 2, 2021 
Dian Ramadan Lazuardi, Sri Murti, Adi Rohman, Sintiyah Permata Sari

Pengembangan Modul Analisis Penggunaan Bahasa Indonesia Mahasiswa Semester VI

Program Studi Pendidikan Bahasa dan Sastra Indonesia di STKIP PGRI Lubuklinggau

Tabel 2. Jumlah Keseluruhan Hasil Validator

\begin{tabular}{lcccccccccccc}
\hline \multicolumn{1}{l}{$\begin{array}{l}\text { Komponen } \\
\text { Kelayakan }\end{array}$} & \multicolumn{1}{c}{ Nomar Pernyataan } & \multirow{2}{*}{ Jumlah } \\
\cline { 2 - 12 } & $\mathbf{1}$ & $\mathbf{2}$ & $\mathbf{3}$ & $\mathbf{4}$ & $\mathbf{5}$ & $\mathbf{6}$ & $\mathbf{7}$ & $\mathbf{8}$ & $\mathbf{9}$ & $\mathbf{1 0}$ & \\
\hline $\begin{array}{l}\text { Penyajian } \\
\text { Kegerafikan }\end{array}$ & dan & 4 & 5 & 4 & 4 & 5 & 4 & 4 & 4 & 4 & 4 & 41 \\
\hline Isi/Materi & & & & & & & & & & & \\
\hline Kebahasaan & 4 & 4 & 4 & 4 & 5 & 4 & 4 & & & 29 \\
\hline
\end{tabular}

2). Evaluasi Prototipe

a. Pelaksanaan Evaluasi One To One

Hasil dari data one to one pada modul Analisis Penggunaan Bahasa Indonesia dilakukan berdasarkan empat indikator yaitu: a) kemenarikan modul; b) keterbacaan isi materi; c) penyajian gambar; d) penyajian materi dalam modul. Berdasarkan hasil dari kegiatan one to one ini, diketahui bahwa modul yang peneliti kembangkan menarik, hal ini dibuktikan dengan antusias mahasiswa terhadap modul. Kemudian, modul yang peneliti kembangkan menggunakan bahasa yang sederhana, dilengkapi dengan contoh-contoh yang sederhana sehingga sangat materi yang ada di dalam modul mudah dipahami, selanjutnya gambar yang diterapkan sesuai dengan kajian materi, serta memuat materi yang lengkap. Berdasarkan hasil tersebut dapat disimpulkan bahwa modul Analisis Penggunaan Bahasa Indonesia yang peneliti kembangkan dapat diterapkan pada mahasiswa dan dosen dalam melaksanakan kegiatan pembelajaran.

\section{b. Pelaksanaan Evaluasi Kelompok Kecil}

Evaluasi kelompok kecil dilaksanakan pada tanggal 7 April 2021, dengan memberikan pertanyaan dalam angket tertutup kepada enam mahasiswa yang diambil secara acak. Angket tersebut terdiri dari 10 butir pertanyaan. Adapun hasil angket evaluasi kelompok kecil tergambar pada tabel di bawah ini:

Tabel 3. Hasil Angket Kelompok Kecil

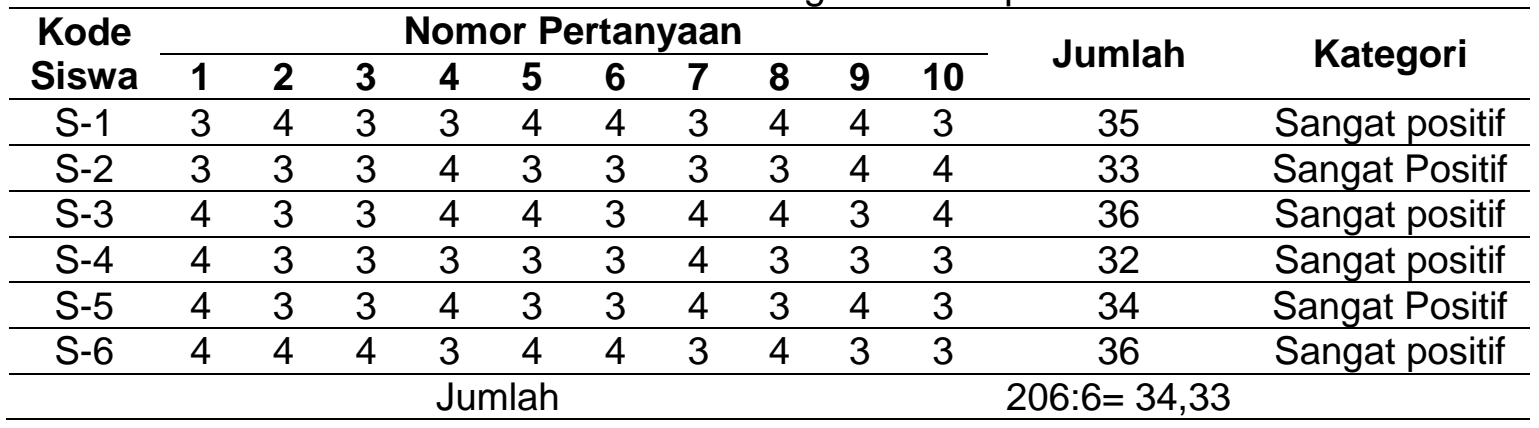

$$
\begin{aligned}
& \mathrm{P}=\frac{\text { skor yang diperolah }}{\text { skor maksimal }} \times 100 \\
& \mathrm{P}=\frac{34,33}{40} \times 100=85.82 \% .
\end{aligned}
$$

Silampari Bisa: Jurnal Penelitian Pendidikan Bahasa Indonesia, Daerah, dan Asing Vol. 4, No. 2, 2021 
Berdasarkan hasil uji coba kelompok kecil, dapat disimpulkan bahwa respons mahasiswa terhadap modul Analisis Penggunaan Bahasa Indonesia sangat positif dengan persentase $85,82 \%$. Hal ini menunjukan bahwa modul Analisis Penggunaan Bahasa Indonesia sudah praktis dan siap digunakan. Selanjutnya, modul Analisis Penggunaan Bahasa Indonesia diujicobakan pada ruang lingkup yang lebih luas guna melihat keefektifannya.

\section{3) Pelaksanaan Uji Lapangan}

Pada tahap terakhir ini, evaluasi yang dilakukan untuk mendapatkan informasi yang mendasar mengenai kualitas produk modul Analisis Penggunaan Bahasa Indonesia. Uji coba lapangan dilakukan pada 20 mahasiswa. Hal ini dilakukan untuk mengetahui keefektifan dan kevalidan bahan ajar. Pelaksanaan uji coba lapangan dilakukan pada hari tanggal 7 April 2021.

$$
\begin{aligned}
& \mathrm{P}=\frac{\text { skor yang diperoleh }}{\text { skor maksimal }} \times 100 \\
& \mathrm{P}=\frac{70,15}{80} \times 100=87,68 \% .
\end{aligned}
$$

Berdasarkan hasil angket uji coba kelompok besar, dapat disimpulkan bahwa respon mahasiswa terhadap modul Analisis Penggunaan Bahasa Indonesia adalah sangat positif dengan persentase $87,68 \%$.

\section{Pembahasan}

Berdasarkan hasil analisis data yang dilakukan oleh peneliti diperoleh data bahwa modul Analisis Penggunaan Bahasa Indonesia valid, efektif dan efisien digunakan dalam proses perkuliahan. Jika dilihat dari hasil desain, hal yang paling menonjol dari modul Analisis Penggunaan Bahasa Indonesia adalah urutan penyajian serta penyajian yang memberikan interaksi (stimulus-respons). Jika dilihat dari komponen kebahasaan secara umum bahasa yang digunakan dalam modul ini adalah bahasa yang mudah dipahami sehingga mahasiswa mampu menangkap informasi yang terdapat dalam modul tersebut. Sementara modul Analisis Penggunaan Bahasa Indonesia dilihat dari komponen isi, tentunya modul ini sesuai dengan tujuan perkuliahan dengan menyesuaikan materi dan soal yang sesuai dengan kebutuhan mahasiswa.

Keberhasilan proses perkuliahan ditunjang dari berbagai unsur salah satunya adalah keberadaan modul Analisis Penggunaan Bahasa Indonesia yang valid, efektif, dan efisien. Dalam proses pengembangan modul ini, melewati 9 tahapan dimulai dengan analisis kebutuhan hingga evaluasi formatif. Berdasarkan hasil wawancara yang dilakukan secara langsung mengenai analisis kebutuhan di awal penelitian, dapat disimpulkan bahwa mahasiswa ingin memiliki buku pegangan Mata Kuliah Analisis Penggunaan Bahasa Indonesia. Dengan memiliki buku pegangan yang terjangkau tersebut, harapan terhadap perkuliahan menjadi menjadi lebih menarik dan sesuai dengan capaian pembelajaran Mata Kuliah Analisis Penggunaan Bahasa Indonesia yaitu mampu mengkaji pokok-pokok tentang analisis kesalahan berbahasa yang berkaitan dengan hakikat, kesalahan 
berbahasa; tujuan analisis kesalahan berbahasa; bentuk kesalahan berbahasa lapses, error (kekhilafan), dan mistake; prosedur analisis kesalahan berbahasa; sumber kesalahan berbahasa; metode analisis kesalahan berbahasa; kategori kesalahan berbahasa; kesalahan berbahasa dalam tataran fonologi; kesalahan berbahasa dalam tataran morfologi; kesalahan berbahasa dalam tataran sintaksis; serta kesalahan berbahasa dalam semantik dan kesalahan berbahasa dalam wacana.

Salah satu bahan ajar yang dapat dikembangkan oleh pendidik adalah bahan ajar yang berbentuk modul. Asyhar (2013:155) menjelaskan bahwa modul adalah salah satu bentuk bahan ajar berbasis cetakan yang dirancang untuk belajar secara mandiri oleh peserta pembelajaran. Oleh karena itu, modul dilengkapi dengan petunjuk untuk belajar sendiri. Dalam hal ini, peserta didik dapat melakukan kegiatan belajar sendiri tanpa kehadiran pengajar secara langsung. Alasan seorang pendidik perlu untuk mengembangkan bahan ajar, antara lain; ketersediaan bahan sesuai tuntutan kurikulum, karakteristik sasaran, dan tuntutan pemecahan masalah belajar. Tujuan pembuatan modul ini adalah memudahkan mahasiswa memahami materi terlebih proses perkuliahan dilakukan secara campuran yaitu daring dan luring. Penelitian ini bertujuan untuk mengetahui pengembangan modul Analisis Penggunaan Bahasa Indonesia yang valid, praktis, dan efektif digunakan dalam proses perkuliahan.

Berdasarkan hasil uji validitas yang dilakukan terhadap ketiga ahli yaitu Dr. M. Syahrun Effendi, M.Pd (ahli kebahasaan), Dr. Dodik Mulyono, M.Pd. (ahli desain/grafis), dan Dr. Satinem, M.Pd. (ahli isi/ materi) disimpulkan bahwa modul Analisis Penggunaan Bahasa Indonesia berada dikategori baik yaitu dengan hasil $81,6 \%$. Selanjutnya, untuk mengetahui kepraktisan maka dilakukan evaluasi prototipe dengan tahapan pelaksanaan one to one, uji kelompok kecil. dan uji kelompok besar.

Hasil dari data one to one pada modul Analisis Penggunaan Bahasa Indonesia dilakukan berdasarkan empat indikator yaitu: a) kemenarikan modul; b) keterbacaan isi materi; c) penyajian gambar; d) penyajian materi dalam modul. Berdasarkan hasil dari kegiatan one to one ini, diketahui bahwa modul yang peneliti kembangkan menarik. Hal ini dibuktikan dengan antusias mahasiswa terhadap modul. Kemudian, modul yang peneliti kembangkan menggunakan bahasa yang sederhana, dilengkapi dengan contoh-contoh yang sederhana sehingga sangat materi yang ada di dalam modul mudah dipahami, selanjutnya gambar yang diterapkan sesuai dengan kajian materi, serta memuat materi yang lengkap. Berdasarkan hasil tersebut dapat disimpulkan bahwa modul Analisis Penggunaan Bahasa Indonesia yang peneliti kembangkan dapat diterapkan pada mahasiswa dan dosen dalam melaksanakan kegiatan pembelajaran.

Berdasarkan hasil uji coba kelompok kecil, dapat disimpulkan bahwa respons mahasiswa terhadap modul Analisis Penggunaan Bahasa Indonesia sangat positif dengan persentase $85,82 \%$. Hal ini menunjukan bahwa modul Analisis Penggunaan Bahasa Indonesia sudah praktis dan siap digunakan. Selanjutnya, modul Analisis Penggunaan Bahasa Indonesia diujicobakan pada ruang lingkup

Silampari Bisa: Jurnal Penelitian Pendidikan Bahasa Indonesia, Daerah, dan Asing Vol. 4, No. 2, 2021 
yang lebih luas guna melihat keefektifannya. Berdasarkan hasil angket uji coba kelompok besar, dapat disimpulkan bahwa respons mahasiswa terhadap modul Analisis Penggunaan Bahasa Indonesia adalah sangat positif dengan persentase $87,68 \%$.

Setelah melakukan uji prototipe, tahapan selanjutnya adalah melakukan evaluasi formatif. Dari hasil tes yang dilakukan, disimpulkan bahwa mahasiswa dapat mengerjakan soal dan tugas yang terdapat dalam modul. Hal ini dibuktikan dari hasil kerja mahasiswa yang sudah dikumpulkan berada dikategori baik. Tes yang diberikan berbentuk tugas menemukan bentuk kategori kesalahan berbahasa yang terdiri dari kategori linguistik, kategori strategi lahir, kategori komparatif, dan kategori efek komunikatif. Rata-rata mahasiswa bisa menemukan contoh dari maisng-masing bentuk kesalahan berbahasa tersebut.

Dengan demikian, modul Analisis Penggunaan Bahasa Indonesia bisa digunakan dan telah terbukti valid dengan kategori sangat baik. Selain itu, respons positif dari mahasiswa terhadap modul ini dapat dipahami dan dapat digunakan sesuai dengan materi perkuliahan sehingga dari hasil pengembangan modul Analisis Kesalahan Berbahasa Indonesia dapat dikatakan valid, praktis dan efesien. Modul ini layak dijadikan sebagai buku ajar bagi mahasiswa yang mengambil Mata Kuliah Analisis Penggunaan Bahasa Indonesia.

\section{Simpulan dan Saran}

Berdasarkan uji validitas, uji kepraktisan, dan uji formatif maka dapat disimpulkan bahwa modul Analisis Penggunaan Bahasa Indonesia valid, praktis, dan efektif. Selanjutnya, saran dalam penelitian ini adalah, bagi peneliti selanjutnya dapat mengembangkan modul Analisis Penggunaan Bahasa Indonesia dengan menambahkan inovasi pembelajaran seperti media atau metode pembelajaran sebagai tambahan materi dalam mengembangkan modul.

\section{Daftar Pustaka}

Arsanti, M. (2018). Pengembangan Bahan Ajar Mata Kuliah Penulisan Kreatif Bermuatan Nilai-Nilai Pendidikan Karakter Religius bagi Mahasiswa Prodi PBSI, FKIP, UNISSULA. Kredo: Jurnal IImiah Bahasa dan Sastra, 1(2), https://jurnal.umk.ac.id/index.php/kredo/article/view/2107

Asyhar, R. (2013). Kreatif Mengembangkan Media Pembelajaran. Jakarta: Gaung Persada Press.

Murti, S., \& Lazuardi, D. (2019). Pengembangan Bahan Ajar Mata Kuliah Konsep Dasar Bahasa dan Sastra Indonesia Berbasis Kontekstual STKIP PGRI Lubuklinggau. Jurnal KIBASP (Kajian Bahasa, Sastra dan Pengajaran), 3(1), $1-16$. https://doi.org/https://doi.org/10.31539/kibasp.v3i1.972 
Dian Ramadan Lazuardi, Sri Murti, Adi Rohman, Sintiyah Permata Sari

Pengembangan Modul Analisis Penggunaan Bahasa Indonesia Mahasiswa Semester VI Program Studi Pendidikan Bahasa dan Sastra Indonesia di STKIP PGRI Lubuklinggau

Pratama, U. (2020). Analisis Gaya Belajar Mahasiswa Pendidikan Seni Pertunjukan Berdasarkan Modalitas Preferensi Sensori. JINOTEP (Jurnal Inovasi dan Teknologi Pembelajaran): Kajian dan Riset dalam Teknologi Pembelajaran, 7(2), 107-115. doi:10.17977/um031v7i22020p107

Putra, H. B., Asim, A., \& Hariyanto, E. (2017). Perbedaan Pengaruh Gaya Mengajar Komando dengan Gaya Mengajar Latihan terhadap Minat Peserta Didik pada Pembelajaran Permainan Bola Voli Kelas X Madrasah. Gelanggang Pendidikan Jasmani Indonesia, 1(2), 252. doi:10.17977/um040v1i2p252-261

Ramadania, F. (2013). Konsep Bahasa Berbasis Teks pada Buku Ajar Kurikulum. Stilistika: Jurnal Bahasa, Sastra, dan Pengajarannya, 1(2), doi.org/10.33654/sti.v1i2.372.

Rohmah, F. (2020). Pengembangan Modul Sintaksis Bermodel Discovery Learning untuk Mahasiswa Pendidikan Bahasa Indonesia. Jurnal Pendidikan Bahasa dan Sastra, 20(1), 111-120. doi:10.17509/bs_jpbsp.v20i1.25976

Sadjati, IM. (2012). Pengembangan Bahan Ajar. file:///C:/Users/Administrator/Downloads/Documents/IDIK4009-TM.pdf. (Diakses pada tanggal 6 Januari 2021, Pukul 13.00 WIB)

Satinem, S., Juwati, J., \& Noermanzah, N. (2020). Developing Teaching Material of Poetry Appreciation Based on Students Competency Analysis. English Review: Journal of English Education, 8(2), 237-246. doi:10.25134/erjee.v8i2.2707

Setyosari, P. (2015). Metode Penelitian Pendidikan dan Pengembangan. Jakarta: Kencana.

Sugiyono. (2013). Metode Penelitian Kualitatif, Kuantitatif, dan R\&D. Bandung: Alfabeta.

Wahayuningrum, T. (2019). Efektivitas Penggunaan Modul terhadap Peningkatan Nilai Akhir Siswa pada Pelajaran Bahasa Inggris. Dinamika Bahasa dan Budaya, 14(1), 1-9. doi:10.35315/bb.v14i1.6710

Widodo, C.S. \& Jasmadi. (2008). Panduan Penyusunan Bahan Ajar Berbasis Kompetensi. Jakarta: PT Gramedia Jakarta.

Silampari Bisa: Jurnal Penelitian Pendidikan Bahasa Indonesia, Daerah, dan Asing Vol. 4, No. 2, 2021 